\title{
Perancangan dan Implementasi Perangkat Akuisisi Data dan Regulasi Daya Pada Sistem
}

\author{
Christopher $^{1 *}$, M Rizki Ramadhan ${ }^{1}$, Inda Dwi Ramadhani ${ }^{1}$, Rheyuniarto Sahlendar A. S.T., M.T. ${ }^{1}$, Swadexi Istiqphara \\ S.T., M.T. ${ }^{1}$ \\ ${ }^{1}$ Institut Teknologi Sumatera \\ Email : *Christopher991104@gmail.com
}

\begin{abstract}
Health is a very important need for humans, health can be obtained by doing sports. the development of technology makes Virtual Reality can be used as a medium to do sports from home. Through this research has been designed and implemented data acquisition and power regulation devices on virtual reality controller systems for sports. the system will be mounted on the bike as a controller. Waterfall research method consists of several stages, namely review, design, verification of components, implementation and testing. Sensor readings will be sent via a series of bluetooth communications in a data packet. The test results can be concluded that the infrared sensor reading has an error of $0.011 \%$, a potentiometer of $0.047 \%$, and a voltage sensor of $0.002 \%$ and has a system average current value of $0.93 \mathrm{~A}$.
\end{abstract}

Keywords : Health, Virtual Reality, data acquisition.

\section{INTISARI}

Kesehatan adalah kebutuhan yang sangat penting untuk manusia, Kesehatan dapat diperoleh dengan melakukan olahraga. berkembangnya teknologi membuat Virtual Reality dapat dimanfaatkan sebagai media untuk melakukan olahraga dari rumah. Melalui penelitian ini telah dirancang dan diimplementasikan perangkat akuisisi data dan regulasi daya pada sistem Virtual Reality kontroler untuk olahraga. sistem akan dipasang pada sepeda sebagai kontroler. metode penelitian waterfall terdiri dari beberapa tahap yaitu tinjauan, perancangan, verifikasi komponen, implementasi dan pengujian. Hasil pembacaan sensor akan dikirimkan melalui serial komunikasi bluetooth dalam sebuah paket data. Hasil pengujian dapat disimpulkan bahwa pembacaan sensor infrared memiliki kesalahan $0,011 \%$, potensiometer $0,047 \%$, dan sensor tegangan $0,002 \%$ serta memiliki nilai arus ratarata sistem sebesar $0,93 \mathrm{~A}$.

Kata kunci: Kesehatan, Virtual Reality, akuisisi data.

\section{PENDAHULUAN}

Pada tahun 2020 awal mula ditemukannya penyakit Corona Disease 2019 (COVID-19). Pertama kali virus COVID-19 dilaporkan pada akhir tahun 2019 di Wuhan, Tiongkok dan kasus awal positif di Indonesia didapatkan pada bulan Maret 2020. Awalnya penyakit ini ada yang menyebut pneumonia, pneumonia Wuhan dan novel coronavirus pneumonia. Sehingga organisasi Kesehatan dunia menyebut dengan nama Coronavirus disease 2019(COVID19) [1].

Kebijakan Physical distancing sebagai upaya memutuskan mata rantai penyebaran virus sehingga berdampak terhadap pola kebiasaan sehari-hari seperti pembatasan aktivitas manusia dalam kegiatan belajar mengajar maupun aktivitas diluar rumah, membuat manusia sulitnya melakukan olahraga dan membuat imunitas tubuh berkurang akibat kurangnya beraktivitas[2].

Kesehatan adalah kebutuhan yang sangat penting untuk manusia. Kesehatan sendiri bisa diperoleh dengan melakukan aktivitas yang cukup, menjaga pola makan sehat, melakukan olahraga secara teratur dan istirahat yang cukup. Berolahraga juga merupakan salah satu aktivitas fisik yang harus dilakukan untuk menjaga tubuh tetap sehat. Dengan melakukan olahraga, manusia dapat menajaga imunitas tubuh tetap 
prima sehingga mengurangi resiko terkena penyakit dan virus. Olahraga sederhana dapat dilakukan didalam rumah seperti melakukan kegiatan senam yang dapat dilakukan adalah bersepeda. Bersepeda merupakan olahraga yang dapat setiap hari dapat lakukan, dimana dengan bersepeda pengguna dapat membakar kalori, melihat pemandangan yang berada disekitarnya membuat manusia merasakan olahraga yang rileks disertai dengan peningkatan aktivitas kerja jantung dalam memompa darah[3].

Dari permasalahan tersebut, maka solusi yang dapat diberikan oleh penulis yaitu dengan membuat simulasi berkendara menggunakan sepeda berbasis Virtual reality. Untuk merealisasikan solusi tersebut maka dibutuhkan perancangan sistem yang baik agar dalam mengimplementasikan lebih terstruktur pada penelitian ini penulis akan melakukan perancangan dan pengimplementasian sistem catu daya dan sistem akuisisi data, dimana penggunaan daya dan sensor sangat penting untuk kebutuhan sistem ini.

Berdasarkan pernyataan diatas maka dilakukan penelitian dengan judul "Perancangan Dan Implementasi Perangkat Akuisisi Data dan Regulasi Daya Pada Sistem Virtual Reality Untuk Olahraga". Harapannya dengan adanya produk ini dapat menjadi solusi untuk permasalahan olahraga.

\section{LANDASAN TEORI}

\section{A. Arduino Uno}

Arduino Uno merupakan sebuah sistem minimum mikrokontroler yang menggunakan chip ATmega328. Arduino Uno sendiri memiliki 14 pin digital input/output, 6 pin tersebut dapat digunakan sebagai output PWM. Memiliki 6 analog input, sebuah osilator kristal $16 \mathrm{MHz}$ juga terdapat pada mikrokontroler, sebuah koneksi USB untuk menghubungkan ke komputer, sebuah power jack sebagai input daya eksternal yang dapat menerima tegangan hingga 12V. Arduino Uno pada sistem digunakan sebagai CPU tempat pemrosesan data terhadap sensor yang dipakai pada sistem. Input daya dapat berupa koneksi USB, adaptor dan baterai[4].

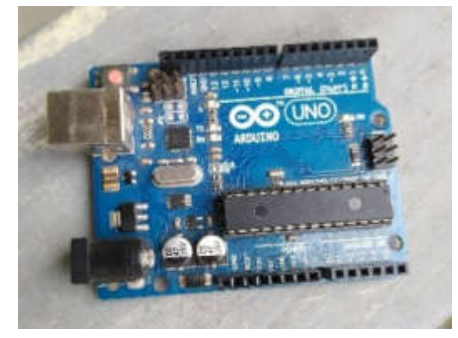

Gambar 1. Arduino Uno

\section{B. Sensor Infrared FC-051}

Sensor infrared adalah sensor yang dapat mendeteksi objek berdasarkan jarak sensor. Pada pemanfaatannya sensor infrared memiliki komponen penting yaitu pemacar infrared dan penerima pantulan infrared. Untuk memancarkan infrared dibutuhkan Infrared Light Emiting Diode (IR LED) sedangkan penerima pantulan infrared dibutuhkan photodioda, panjangnya pancaran infrared dapat diatur dengan menggunakan potensiometer jika diputar searah jarum jam akan meningkatkan panjang pancaran infrared, dan apabila berlawanan arah jarum jam maka akan mengurangi panjang pancaran infrared. Terdapat IC komparator pembanding tegangan input dan tegangan referensi yaitu IC LM393[5].

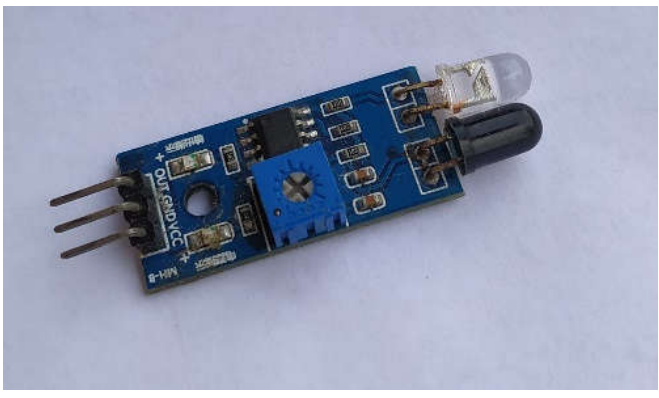

Gambar 2. Sensor infrared

\section{Potensiometer}

Potensiometer adalah salah satu jenis resistor yang menggunakan prinsip resistansi variabel maka resistor ini dapat digunakan dengan mengatur nilai resistansi sesuai dengan kebutuhan. Potensiometer memiliki sudut putar hingga $\pm 300^{\circ}$ dengan mengirimkan tegangan variabel pada mikrokontroler sehingga menghasilkan nilai ADC yang didapat dikonversikan dalam bentuk sudut [6].

\section{Sensor Tegangan}

Sensor tegangan merupakan sebuah modul sensor yang didalamnya terdapat komponen resistor R1 dan R2 menggunakan prinsip pembagi tegangan. 
Modul ini pada perhitungannya dapat mengurangi membuat tegangan inputnya berkurang 5 kali dari tegangan awalnya. Pada input pin analog maksimum input mikrokontroler yaitu 5 volt, sehingga modul ini dapat memuat tegangan tidak lebih dari 25V. Gambar modul sensor tegangan adalah seperti Gambar 3 . Dasar dari pembacaan sensor hanya mengubah nilai tersebut ke bentuk bilangan dari 0 sampai 1023, modul ini membaca nilai tegangan dengan membandingkan dengan nilai tegangan reff [7].

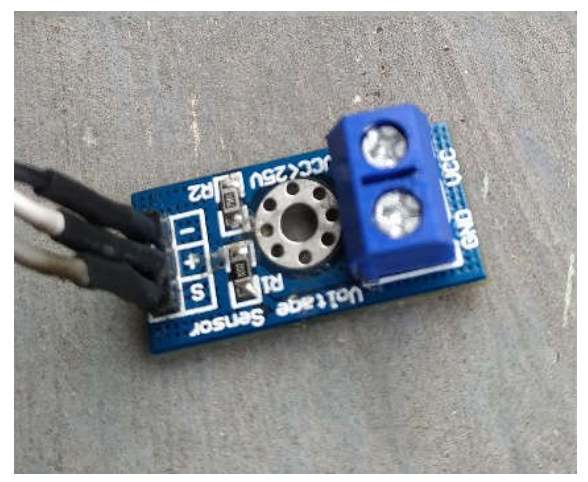

Gambar 3. Sensor tegangan

\section{E. Modul BMS}

Modul PCB BMS 2s 20A 7,4-8,4V 18650 Baterai lithium ion pada subsistem daya sebagai managemen baterai yang memiliki fungsi sebagai pengatur sistem pengisian baterai maupun pemakaian baterai pada rangkaian seri baterai li-ion $2 \mathrm{~s}$, sehingga pemerataan kinerja baterai lebih optimal untuk mendapatkan umur pakai baterai yang lebih lama. Modul PCB BMS 2s 20A baterai lithium ion juga dilengkapi dengan pengaman over charge, over discharge dan short circuit. Setiap baterai lithium memiliki voltase 3,6-3,7 V/DC. Dengan 2 baterai akan mencapai voltase rata-rata $7.4 \mathrm{~V} / \mathrm{DC}[8]$.

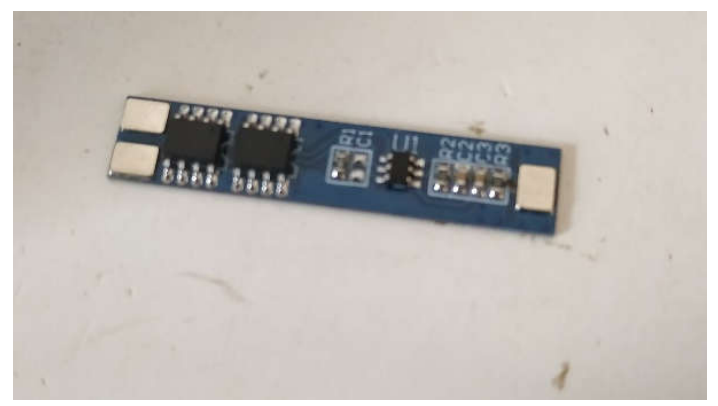

Gambar 4. Modul BMSBaterai Lithium Ion 18650

F. Baterai Lithium Ion 18650
Baterai Li-Ion yang digunakan pada sistem device adalah Li-Ion $2100 \mathrm{mAh}$ dengan kapasitas $3,7 \mathrm{~V}$ untuk satu baterai dan baterai disusun secara 2 seri. Kelebihan menggunakan baterai lithium ion adalah biaya produksi lebih murah, unggul dalam perawatan dan tipe baterai lithium ion tidak mengandung bahan berbahaya sehingga aman untuk digunakan[9]. Tegangan nominal baterai yaitu 3.6V / $3.7 \mathrm{~V}$ dan tegangan maksimal ketika full adalah $4,2 \mathrm{~V}$

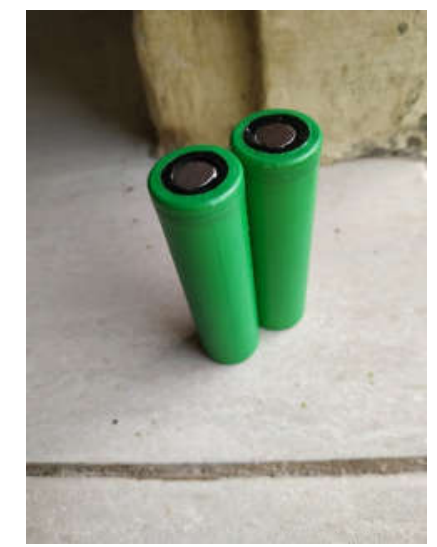

Gambar 5. Baterai lithium ion 18650

\section{METODE PENELITIAN}

Penelitian dilakukan pada sistem yaitu subsistem sensor dan daya terdiri dari analisis akan pembuatan dan integrasi antara kedua subsistem tersebut agar subsistem berjalan sesuai dengan perancangan. Penelitian ini terdiri dari analisis dan pengujian perangkat keras atau hardware dari sistem, Adapun metodologi yang diterapkan pada penelitian ini yaitu metode warterfall[10]. ditunjukkan pada Gambar 6.

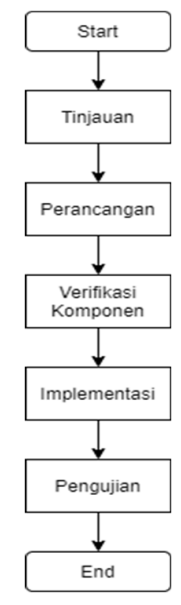

Gambar 6. Metode waterfall 
Pada tahap awal penulis melakukan tinjauan penelitian-penelitian yang akan di teliti mengenai pembuatan sistem daya dan sensor, melalui tinjauan penelitian ini penulis dapat memperoleh informasi mengenai hardware yang akan digunakan spesifikasi serta kelebihan dan kekurangan dari tiap-tiap hardware. Dengan membandingkan beberapa hardware tersebut maka diperoleh hasil hardware yang cocok digunakan pada sistem ini. Pada tahap ini juga meninjau komponen-komponen tambahan yang ditentukan pada tahap perancangan, serta meninjau dan menguji.

Pada tahap perancangan, penulis menentukan cara kerja alat dan desain rancang posisi sensor. Kemudian menentukan komponen yang sesuai dengan hasil rancangan dan skema yang telah dibuat.

Tahap verifikasi kerja komponen yang akan digunakan. Melakukan pengetesan sensorberdasarkan hasil output yang diinginkan, jika tidak sesuai maka komponen dapat diganti dengan kebutuhan sistem agar memastikan sistem dapat bekerja dengan maksimal.

Tahap mengimplementasikan rancangan alat sehingga terbentuk perangkat hardware yang telah siap untuk dioperasikan oleh pengguna dan siap diuji, pada tahap ini penempatan komponen sensor dan daya pada sistem haruslah ditempat yang sesuai dan sesuai dengan rancangan.

Tahap terakhir adalah melakukan pengujian terhadap sistem secara keseluruhan dengan menggunakan metode-metode pengujian yang ada, jika hasil pengujian mendapatkan data yang sangat baik maka kesimpulannya adalah sistem telah dapat digunakan oleh pengguna dan pemecahan masalah telah terselesaikan.

\section{A. Blok Diagram Sistem}

Pada blok diagram terdapat subsistem sensor dan daya. Komponen utama pada subsistem ini adalah sensor infrared, potensiometer, dan baterai 18650 berfungsi sebagai kontroler sistem dan input daya pada sistem. Pada perancangan ini sistem dapat mengirim hasil output sensor dari mikrokontroller ke interface dengan serial komunikasi bluetooth. Penelitian ini akan membahas mengenai subsistem daya dan sensor penyusunan diagram seperti Gambar 7 .

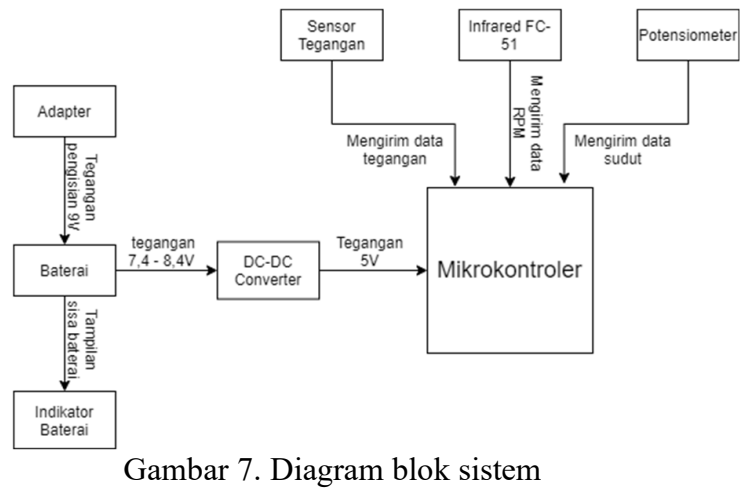

\section{B. Perancangan Pendeteksi Gerak Roda}

Pada perancangan ini menggunakan sensor infrared untuk mengukur kecepatan roda berputar. Sensor dirancang agar mendeteksi indikator lubang yang berada pada roda sepeda.

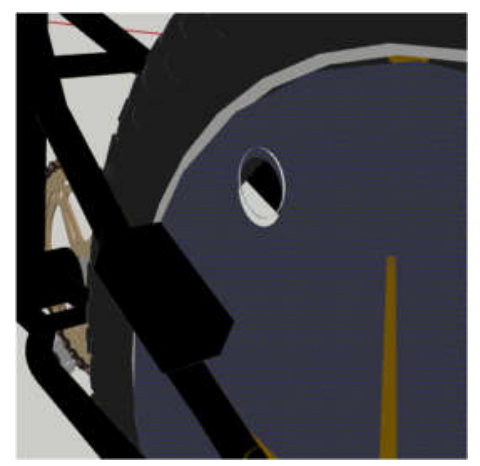

Gambar 8. Sketsa 3D perancangan kecepatan roda

\section{Perancangan Heading}

Sensor yang digunakan dalam perancangan ini adalah potensiometer. Sensor ini dimanfaatkan sebagai heading pada sepeda dikarenakan Sensor ini dapat digunakan dengan mudah dan minimum error.

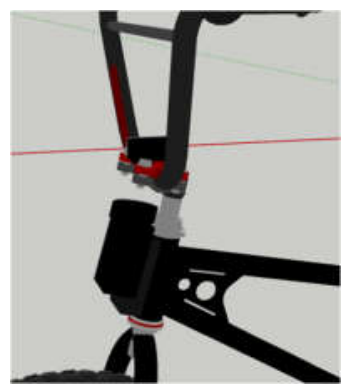

Gambar 9. Sketsa 3D Perancangan Heading

\section{Perancangan Input Catu Daya}

Perancangan catu daya pada sistem menggunakan baterai 18650 dan untuk charging baterai menggunakan modul BMS (battery management system) yang khusus 
digunakan untuk baterai 18650. pada penelitian ini baterai lithium ion yang digunakan dengan kapasitas 2100 mAh sebanyak 2 buah yang disusun secara seri.

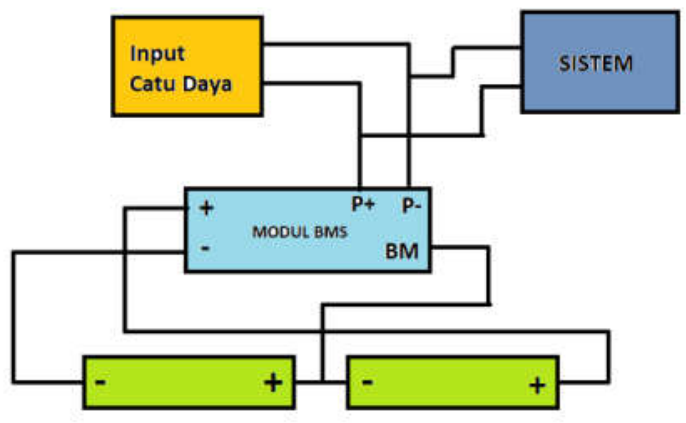

Gambar 10. Circuit rangkaian baterai

\section{E. Perancangan Sistem Keseluruhan}

Komponen box merupakan sebuah box yang digunakan sebagai wadah implementasi bagi beberapa sensor maupun modul yang digunakan pada produk ini. Pada subsistem mikrokontroler, baterai, modul charging dan sensor tegangan disusun dalam komponen box. Perancangan komponen box harus diperhatikan untuk penempatannya agar sistem dapat terlihat lebih menarik.

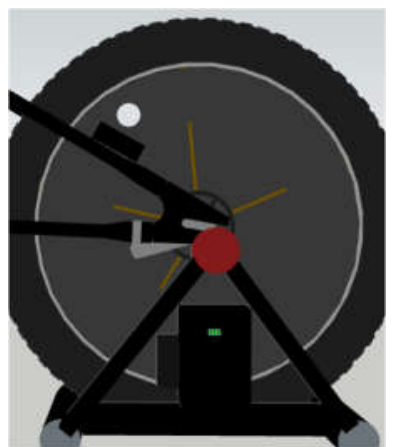

Gambar 11. Sketsa 3D komponen box

Perancangan sistem keseluruhan sistem dapat dilihat pada Gambar 12.

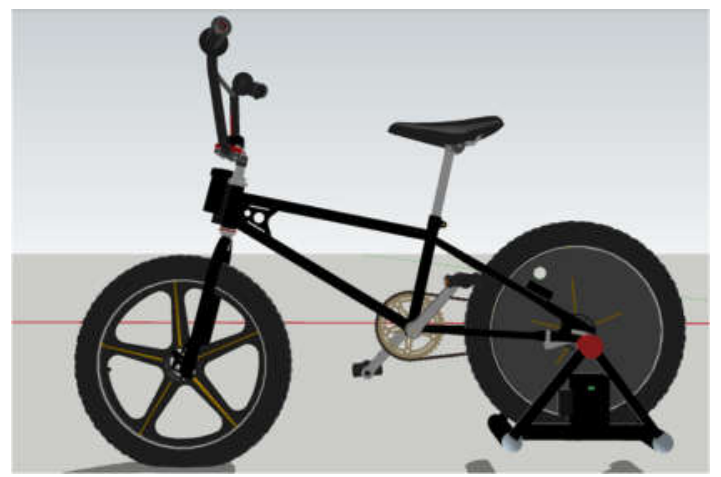

Gambar 12. Sketsa 3D perancangan sistem keseluruhan

\section{HASIL PENELITIAN DAN PEMBAHASAN}

Pengujian dilakukan untuk melihat tingkat akurasi dari data yang dihasilkan pada tiap-tiap sensor dan komponen yang digunakan, pada tahap ini terdapat dua pengujian keseluruhan pada sistem yaitu pengujian akurasi sensor dan pengujian daya pada sistem.

\section{A. Pengujian Kecepatan Putaran Roda}

Pengujian ini bertujuan untuk mengetahui pembacaan sensor infrared untuk mengukur kecepatan putaran roda dengan membandingkan pembacaan pada tachometer non-contact. Data pengujian dapat diamati pada Tabel 1.

Tabel 1. Data pengujian kecepatan

\begin{tabular}{|c|c|c|c|}
\hline No & $\begin{array}{c}\text { Data } \\
\text { Tachometer } \\
(\mathrm{Rpm})\end{array}$ & $\begin{array}{c}\text { Data Serial } \\
\text { Monitor (Rpm) }\end{array}$ & Error(\%) \\
\hline 1 & 72,67 & 73 & 0,004541 \\
\hline 2 & 82,79 & 84 & 0,014615 \\
\hline 3 & 99 & 100 & 0,010101 \\
\hline 4 & 116,6 & 115 & 0,013722 \\
\hline 5 & 119,8 & 120 & 0,001669 \\
\hline 6 & 129,2 & 132 & 0,021672 \\
\hline 7 & 132,3 & 135 & 0,020408 \\
\hline 8 & 142,5 & 144 & 0,010526 \\
\hline 9 & 143,6 & 144 & 0,002786 \\
\hline 10 & 150,1 & 151 & 0,005996 \\
\hline 11 & 151,8 & 154 & 0,014493 \\
\hline 12 & 164,3 & 167 & 0,016433 \\
\hline 13 & 177 & 180 & 0,016949 \\
\hline 14 & 188,1 & 189 & 0,004785 \\
\hline 15 & 195,1 & 192 & 0,015889 \\
\hline 16 & 198,5 & 201 & 0,012594 \\
\hline 17 & 205 & 209 & 0,019512 \\
\hline
\end{tabular}


Jurnal ELECTRON, Vol. 2, No.1, Mei 2021, Hal. 34-40

e-ISSN 2622-6588

\begin{tabular}{|c|c|c|c|}
\hline No & $\begin{array}{c}\text { Data } \\
\text { Tachometer } \\
(\mathrm{Rpm})\end{array}$ & $\begin{array}{c}\text { Data Serial } \\
\text { Monitor (Rpm) }\end{array}$ & Error $(\%)$ \\
\hline 18 & 219,3 & 222 & 0,012312 \\
\hline 19 & 227 & 228 & 0,004405 \\
\hline 20 & 250,9 & 254 & 0,012356 \\
\hline
\end{tabular}

Hasil pengujian menunjukkan bahwa sensor infrared FC-05 memiliki kemampuan pembacaan yang baik sehingga nilai rata-rata eror pembacaan 0,011 . Dari hasil pengujian kecepatan putaran roda sudah sangat baik dan pengujian telah mendapatkan data yang sesuai yang diharapkan.

\section{B. Pengujian Sudut Header}

Pengujian ini bertujuan untuk mengetahui pembacaan Potensiometer untuk mengukur sudut dengan membandingkan pembacaan pada busur. Data pengujian dapat diamati pada Tabel 2 .

Tabel 2. Data pengujian sudut header

\begin{tabular}{|c|c|c|c|}
\hline No & $\begin{array}{c}\text { Data } \\
\text { Busur }\left({ }^{\circ}\right)\end{array}$ & $\begin{array}{c}\text { Data Serial } \\
\text { Monitor }\left({ }^{\circ}\right)\end{array}$ & Error $(\%)$ \\
\hline 1 & 5 & -6 & 0,2 \\
\hline 2 & 10 & -11 & 0,1 \\
\hline 3 & 15 & -15 & 0 \\
\hline 4 & 20 & -19 & 0,05 \\
\hline 5 & 25 & -23 & 0,08 \\
\hline 6 & 30 & -31 & 0,033333 \\
\hline 7 & 35 & -34 & 0,028571 \\
\hline 8 & 40 & -40 & 0 \\
\hline 9 & 45 & -44 & 0,022222 \\
\hline 10 & 50 & -48 & 0,04 \\
\hline 11 & 55 & -56 & 0,018182 \\
\hline 12 & 60 & -58 & 0,033333 \\
\hline 13 & 65 & -64 & 0,015385 \\
\hline
\end{tabular}

Hasil pengujian menunjukkan bahwa potensiometer kemampuan pembacaan yang baik sehingga nilai rata-rata error pembacaan 0,047. Dari hasil pengujian sudut header sudah sangat baik dan pengujian telah mendapatkan data yang sesuai yang diharapkan.

\section{Pengujian Sensor Tegangan}

Pengujian ini bertujuan untuk mengetahui pembacaan sensor tegangan untuk mengukur tegangan pada sistem dengan membandingkan pembacaan pada multimeter digital. Data pengujian dapat diamati pada Tabel 3.
Tabel 3. Data pengujian sensor tegangan

\begin{tabular}{|c|c|c|r|}
\hline No & $\begin{array}{c}\text { Data } \\
\text { Multimeter }\end{array}$ & $\begin{array}{c}\text { Data Serial } \\
\text { Monitor }\end{array}$ & Error(\%) \\
\hline 1 & 4 & 3,98 & 0,005 \\
\hline 2 & 4,5 & 4,5 & 0 \\
\hline 3 & 5 & 4,99 & 0,002 \\
\hline 4 & 5,5 & 5,47 & 0,005455 \\
\hline 5 & 6 & 5,99 & 0,001667 \\
\hline 6 & 6,5 & 6,48 & 0,003077 \\
\hline 7 & 7 & 6,99 & 0,001429 \\
\hline 8 & 7,5 & 7,48 & 0,002667 \\
\hline 9 & 8 & 7,99 & 0,00125 \\
\hline 10 & 8,5 & 8,48 & 0,002353 \\
\hline 11 & 9 & 8,99 & 0,001111 \\
\hline 12 & 9,5 & 9,51 & 0,001053 \\
\hline 13 & 10 & 10 & 0 \\
\hline 14 & 10,5 & 10,48 & 0,001905 \\
\hline
\end{tabular}

Hasil pengujian menunjukkan bahwa sensor tegangan kemampuan pembacaan yang baik sehingga nilai rata-rata eror pembacaan 0,002 . Dari hasil pengujian sensor tegangan sudah sangat baik dan pengujian telah mendapatkan data yang sesuai yang diharapkan.

\section{Pengujian Konsumsi Arus Sistem}

Pengujian arus pada sistem menggunakan sensor arus untuk mendapatkan melihat grafik perubahan kondisi arus pada sistem. Grafik pengujian dapat dilihat pada Gambar 13.

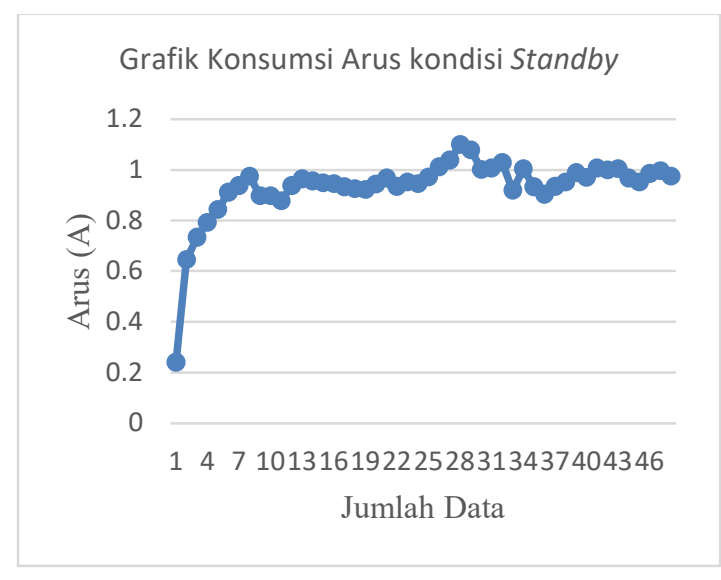

Gambar 13. Grafik konsumsi arus sistem

Hasil pengujian konsumsi arus sistem dapat dilihat pada gambar 12. Arus mula-mula memiliki nilai $0,2 \mathrm{~A}$ beranjak naik pada nilai arus tertinggi yaitu 1,009 A dengan nilai rata-rata arus yaitu $0,93 \mathrm{~A}$. maka dapat 
dinyatakan nilai konsumsi daya sistem rata rata yaitu sebesar 4,65 W. Dari hasil pengujian konsumsi arus sistem sudah sangat baik dan pengujian telah mendapatkan data yang sesuai yang diharapkan.

\section{KESIMPULAN}

Berdasarkan hasil pengujian yang telah dilakukan serta menganalisis setiap sensor yang digunakan, maka penulis dapat menarik kesimpulan sebagai berikut:

1. Berdasarkan data sensor infrared yang diperoleh dari pengujian perbandingan antara data serial monitor dengan ukur alat tachometer digital didapatkan nilai error ratarata sebesar $0,011 \%$.

2. Hasil pengujian potensiometer untuk mengukur akurasi sudut perbandingan antara data serial monitor dan data hasil pengujian menggunakan busur didapatkan nilai error rata-rata sebesar $0,047 \%$.

3. Hasil pengujian sensor tegangan terhadap tegangan baterai pada sistem dilakukan perbandingan antara data serial monitor dengan hasil pengukuran multimeter digital didapatkan data error rata-rata sebesar $0,002 \%$.

4. Hasil pengujian konsumsi arus sistem didapatkan nilai rata-rata arus sebesar 0,93 A, sehingga daya rata-rata sistem adalah sebesar $4,65 \mathrm{~W}$.

\section{REFERENSI}

[1] Arif Wicaksono. "AKTIVITAS FISIK YANG AMAN PADA MASA PANDEMI COVID19." Jurnal Ilmu Keolahragaan Undiksha., vol. 8, no. 1, hal. 10, 2020.

[2] Kunjung dkk. "Pola aktivitas olahraga sebelum dan selama masa pandemi covid-19 pada mahasiswa fakultas olahraga dan fakultas nonolahraga." Jurnal SPORTIF: Jurnal Penelitian Pembelajaran., vol. 6, no. 3, pp. 713-728, 2020.

[3] Adam, Fat'hah dkk. "Sistem Sepeda Statis Menggunakan Beban Dinamis Berbasis Realitas Virtual Yang Tersinkronisasi Dengan Konten Vidio 360 Derajat.” Jurnal Ilmu Terapan., vol. 5, no. 2, hal. 1-4, 2019.
[4] Farnell, “Arduino Uno Manual," 2020. https://www.farnell.com/datasheets/1682209.p df (diakses Januari 12, 2021).

[5] M. Irsyam dkk," PERANCANGAN ALAT PENDETEKSI KELAYAKAN OLI PADA KENDARAAN SEPEDA MOTOR BERBASIS ARDUINO UNO ATMEGA328," Jurnal, Elektronika, Universitas Riau Kepuluan Batam, 2019.

[6] Jameco, "Snap-in Insulated Shaft Potentiometer Product Line," 2020. https://www.jameco.com/Jameco/Products/Pr odDS/2272207.pdf (diakses April 12, 2021).

[7] Muhammad Rizal Fachri dkk." Pemantauan Parameter Panel Surya Berbasis Arduino secara Real Time." Jurnal Rekayasa Elektrika., vol. 11, no. 4, hal. 1234- 125, 2015.

[8] Robu.in, "2S 20A 18650 Lithium Battery Protection Board," 2020. https://robu.in/product/2s-20a-18650-lithiumbattery-protection-board/ (diakses Januari 12, 2021).

[9] Sony Corporation, "Lithium Ion Rechargeable Battery Technical Information Datasheet," Sony Energy Devices Corporation Device Solutions Business Group, 2015. https:/www.kronium.cz/uploads/SONY_US1 8650VTC6.pdf (diakses Januari 12, 2021).

[10] Nur Hidayati. "Penggunaan Metode Waterfall Dalam Rancang Bangun Sistem Informasi Penjualan." Generation Journal., vol. 3, no. 1, hal. 1-4, 2019. 